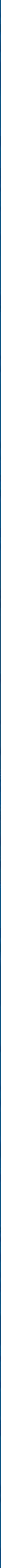




\section{Sumário}

I. Dossiê Especial: Exclusions and its Critics: Southern Narratives of

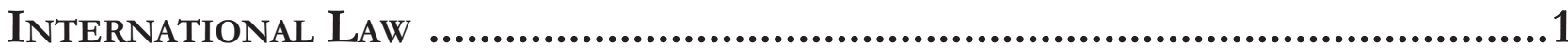

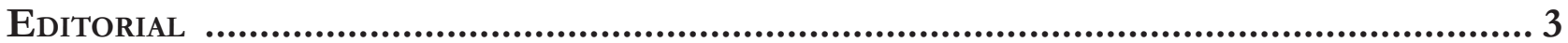

Conseguimos pensar em narrativas críticas do Direito Internacional no Sul Global? ......................... 3

ENTRE A APOLOGIA E A UTOPIA: A POLÍTICA Do DIREITO INTERNACIONAL................................ 6 Martti Koskenniemi e Tradutor João Roriz

A POLÍTICA Do DIREITO INTERNACIONAL: 20 ANOS DEPOIS ...................................................31 Martti Koskenniemi e Tradutor João Roriz

Abordagens terceiro-mundistas para o Direito Internacional: Um Manifesto............42 Bhupinder S. Chimni

Around the pyramid: Political-theoretical challenges to law in the age of global GOVERNANCE

Salem Hikmat Nasser e José Garcez Ghirardi

VOICE AND EXIT: HOW EMERGING POWERS ARE PROMOTING INSTITUTIONAL CHANGES IN THE INTERNATIONAL MONETARY SYSTEM

Camila Villard Duran

LA LIBRE AUTODETERMINACIÓN DE LOS PUEBLOS EN EL SIGLO XXI: UNA APROXIMACIÓN DE LA HISTORIA DEL COLONIALISMO Y EL NEO-COLONIALISMO DESDE LOS PUEBLOS DEL TERCER MUNDO

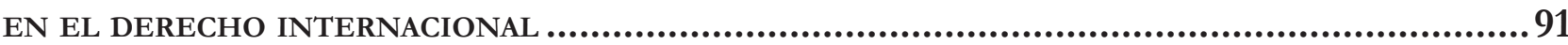

Germán Medardo Sandoval Trigo

INTERNATIONAL CLIMATE CHANGE REGIME AS A PROMOTER OF COLONIAL SYSTEMIC AND SYMBOLIC VIOLENCE: ITS RELATIONSHIP WITH INTERNATIONAL ENVIRONMENT SECURITY AND FOOD SYSTEM THRU THE LENS OF FEMINIST APPROACH 106

Douglas Castro e Bruno Pegorari 
Jus COGENS: AN EUROPEAN CONCEPT? AN EMANCIPATORY CONCEPTUAL REVIEW FROM THE INTER-AMERICAN SYSTEM OF HUMAN RIGHTS

Tatiana de A. F. R. Cardoso Squeff e Marina de Almeida Rosa

O CONHECIMENTO TRADICIONAL RELACIONADO AO COMPLEXO DO CURARE E A LEGISLAÇÃO IN-

TERNACIONAL SOBRE PROPRIEDADE INTELECTUAL. 139

Marcos Vinício Chein Feres e João Vitor de Freitas Moreira

II. Artigos sobre outros temas

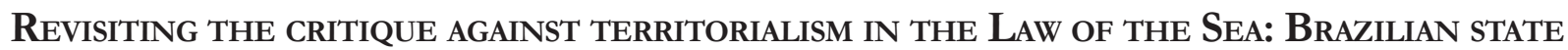
PRACTICE IN LIGHT OF THE CONCEPTS OF CREEPING JURISDICTION AND SPOLIATIVE JURISDICTION ..161 Victor Alencar Mayer Feitosa Ventura

EDUCAÇÃO SUPERIOR INTERCULTURAL, RECONHECIMENTO E REDISTRIBUIÇÃO: O DURO CAMINHO DOS POVOS INDÍGENAS NO EQUADOR 180

Vanessa Wendhausen Cavallazzi, Patrícia Perrone Campos Mello e Raony Soares

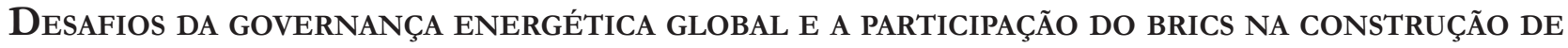
UM NOVO PARADIGMA ENERGÉTICO 200

Fernanda Volpon e Marilda Rosado de Sá Ribeiro

A hermeneutical analysis on the recognition of China as a market economy after 2016.

Alberto Amaral Júnior e Aline Pereira de Carvalho Heringer

THE ISIS ERADICATION OF CHRISTIANS AND YAZIDIS: HUMAN TRAFFICKING, GENOCIDE, AND THE MISSING INTERNATIONAL EFFORTS TO STOP IT

Sarah Myers Raben

The strategic prudence of The Inter-American Court of Human Rights: Rejection OF REQUESTS FOR AN ADVISORY OPINION 255

Cecilia M. Bailliet

Direito Internacional Monocromático: PREVISÃo e apliCaÇÃo dos Direitos LGBTI NA ORDEM INTERNACIONAL 278

Rafael Carrano Lelis e Gabriel Coutinho Galil 
III. RESENHAS

Resenha do livro Empire de Michael Hardt e Antonio Negri 301 Arthur Roberto Capella Giannattasio

Resenha do livro Imperialism, Sovereignty and the Making of International LaW, de

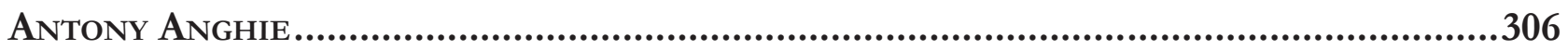

Fabrício José Rodrigues de Lemos e Laura Madrid Sartoretto 


\title{
Voice and exit: How emerging powers are promoting institutional changes in the international monetary system*
}

\author{
Voz e saída: Como os países emergentes \\ estão promovendo mudanças institucionais no \\ sistema monetário internacional
}

Camila Villard Duran**

\section{Abstract}

In the aftermath of the 2008 crisis, emerging powers engaged in political and legal strategies to challenge the actual framework for global monetary governance. This article examines two categories of monetary strategies designed as "voice" and "exit" plans (Hirschman 1970). In the case of the former, they aimed at gaining more participation inside the International Monetary Fund (IMF). In the latter case, strategies were built as legal alternatives to manage future liquidity crises outside the current framework. Using this theoretical classification, this paper identifies institutional responses formulated by the G20 emerging powers in Asia and Latin America after 2008 crisis. The specific approach proposed by this article is to analyze how the legal framework for the management of international money influences their strategies' designs and outcomes. Up to the present, it seems voice strategies are promoting only incremental modifications in institutions. Exit strategies, however, have the potential to be more successful. These strategies have been built as a network of bilateral swap contracts between central banks. Asian powers are more engaged in this type of legal strategy. Latin American countries tend to be recipients of these plans. Exit strategies, however, are moving multilateral cooperation away from the IMF, reinforcing institutional fragmentation and uncertainty on how the next liquidity crises would be managed.

Keywords: international monetary system, international monetary architecture, International Monetary Fund (IMF), international money, central bank swap contracts.

* Recebido em 30/10/2017 Aprovado em 21/12/2017

** Professora Doutora do Departamento de Filosofia e Teoria Geral do Direito (DFD), Faculdade de Direito da Universidade de São Paulo (FDUSP). Email: camiladuran@usp.br

\section{Resumo}

No pós-crise de 2008, países emergentes formularam estratégias jurídicas e políticas para contestar o atual arcabouço institucional da governança monetária global. Este artigo examina duas categorias de estratégias monetárias, identificadas como planos de "voz" e de "saída" (Hirschman 1970). Em relação às primeiras, o objetivo era alcançar maior participação no âmbito do Fundo Monetário Internacional (FMI). Quanto às segundas, as estraté- 
gias foram construídas como alternativas jurídicas para a gestão de futuras crises de liquidez, fora do marco vigente. Valendo-se dessa classificação teórica de Hirschman, este artigo identifica as respostas institucionais formuladas pelos países emergentes da América Latina e da Ásia, membros do G-20, após a crise de 2008. A abordagem específica proposta por este artigo consiste em analisar como o arcabouço jurídico para a gestão monetária internacional influencia o desenho de suas estratégias e de seus resultados. Até o presente, percebe-se que as estratégias de voz estão promovendo apenas modificações incrementais nas instituições. As estratégias de saída, por outro lado, têm maior potencial de êxito. Tais planos têm se apoiado em uma rede de contratos bilaterais de swap de moeda entre bancos centrais. As potências asiáticas têm se empenhado mais ativamente nesse tipo de estratégia jurídica. Os países latino-americanos, por sua vez, tendem a figurar na posição de receptores. As estratégias de saída estão, contudo, afastando a cooperação multilateral do FMI, reforçando a fragmentação institucional global e as incertezas sobre como será implementada a gestão de uma próxima crise de liquidez.

Palavras-chave: sistema monetário internacional, arquitetura monetária internacional, Fundo Monetário Internacional (FMI), moeda internacional, contratos de swap de moedas entre bancos centrais.

\section{INTRODUCTION}

The global financial architecture has been stable since the end of World War II and the establishment of the Bretton Woods institutions. ${ }^{1}$ Since its creation, the International Monetary Fund's (IMF) responsibilities on monetary governance evolved along with significant changes in the international financial system. ${ }^{2}$ Howe-

1 The single exception was the creation of the Financial Stability Board (FSB). The FSB has its headquarters at the Bank for International Settlements (BIS) in Basel, Switzerland.

2 For a critical and special account on the history of international monetary cooperation, see James, H. (1996) International Monetary Cooperation Since Bretton Woods, Oxford University Press, Oxford. For the history of the IMF, see Boughton, J. M. (2001) Silent Revolution: The International Monetary Fund, 1979- 1989, International Monetary Fund, Washington DC.; De Vries, M. G., Horsefield, J.K. (1969) The International Monetary Fund, 19451965: Twenty Years of International Monetary Cooperation, Volume II: Analysis, International Monetary Fund, Washington DC.; De Vries, M. G. (1976) The International Monetary Fund, 1966- ver, it has maintained its governance structure relatively constant with the predominance of traditional powers in the decision-making process and a special role assigned to the United States and its currency.

In the last three decades, however, a major shift in global economic power has occurred, but governance structures in the monetary field did not adjust accordingly. The share in global GDP (PPP basis) ${ }^{3}$ for advanced economies changed from more than 58\% in 1992 to approximately $43 \%$ in 2014 . In the same period, the share for emerging and developing countries increased from $41 \%$ to $57 \%$, respectively, and it is expected to be more than $60 \%$ in $2020 .{ }^{4}$ Nevertheless, emerging and developing economies' share in the IMF quotas only changed (and after long periods of negotiations) from 36\% in 1992 to $42.4 \%$ in 2016.

In the post- 2008 crisis, the emerging countries in the Group of $20(\mathrm{G} 20)^{5}$ called for changes in the balance of voting power at the Fund, arguing that the IMF's decisions would be more legitimate and efficient in responding to emerging needs of monetary cooperation. ${ }^{6}$ There is a demand for more participation and representation in international institutions to better reflect the global shift of economic power.

This article focuses on the fundamental changes that happened within monetary governance at the global

1971: The System Under Stress, Volume I: Narrative, International Monetary Fund, Washington DC. and De Vries, M. G. (1985) The International Monetary Fund, 1972-1978, Volume I: Narrative and Analysis, International Monetary Fund, Washington DC.

3 PPP means Purchasing Power Parity.

4 Source: IMF statistics.

5 The G20 is an informal network created in 1999, after the Asian and Latin American liquidity crises. It became an important forum for global governance when an inaugural leaders' summit in 2008 brought together the head of states and governments of these countries. See the Communiqués of London and Seoul Summits at: https://www.g20.org

6 In 2009, the G20 communiqué of the London Summit registered that: "[i]n order for our financial institutions to help manage the crisis and prevent future crises we must strengthen their longer term relevance, effectiveness and legitimacy. So alongside the significant increase in resources agreed today we are determined to reform and modernise the international financial institutions to ensure they can assist members and shareholders effectively in the new challenges they face. We will reform their mandates, scope and governance to reflect changes in the world economy and the new challenges of globalisation, and that emerging and developing economies, including the poorest, must have greater voice and representation. This must be accompanied by action to increase the credibility and accountability of the institutions through better strategic oversight and decision making" (item 20, G20 London Summit - Leaders' Statement 2 April 2009). 
level, notably involving the IMF. The goal is to stress the modifications on institutional arrangements in the aftermath of the 2008 crisis and identify how the emerging powers in Asia and Latin America are formulating their "voice" and "exit" strategies. ${ }^{7}$ This theoretical framework is helpful to describe two kinds of monetary actions, which emerging countries are adopting in relation to global monetary governance: (1) member countries are expressing their dissatisfaction with the management of monetary affairs at the Fund (voice option); and (2) some member countries are pursuing other institutional arrangements, with the same functions of the IMF, to promote monetary cooperation at the international level (exit option).

In the case of monetary governance, up to the present, there is no decline in the Fund's membership, as the traditional framework of Albert O. Hirschman would suggest. However, this theoretical approach allows us to investigate how voice and exit options come into play jointly and interact with each other, reinforcing themselves in particular situations related to the management of international money and to the legal design of its framework.

Voice and exit strategies are creating an impact on global monetary architecture and reinforcing institutional fragmentation through the emergence of a network of bilateral and regional arrangements based on currency swaps ${ }^{8}$ among central banks. In this sense, the combination of voice and exit monetary strategies could be described as "contested multilateralism".?

This concept emphasizes that "contemporary multilateralism is characterized by competing coalitions and shifting institutional arrangements, informal as well as formal". ${ }^{10}$ The main institutional innovation for monetary governance is the creation of bilateral and regional arrangements based on currency swaps, which have a multilateral intent: to promote monetary cooperation at the global level. There is a difference, however: the

7 HIRSCHMAN, A. O. Exit, voice, and loyalty: Responses to decline in firms, organizations, and states. Cambridge: Harvard University Press, 1970.

8 In a currency swap agreement, a central bank swaps its own currency for another (usually, a stronger currency) and assumes the obligation of repurchasing its currency on a later date at a predetermined rate.

9 Morse, J. C., Keohane, R. O. (2014) "Contested Multilateralism". The Review of International Organizations 9.4.

10 MORSE, J. C., KEOHANE, R. O. Contested Multilateralism..., 2014, p. 386 (note 10, above). cooperation is based on central banks' actions - and not on international organizations' arrangements. This is an important change in terms of institutional design of international monetary governance with the emergence of other types of formal agreements.

Therefore, I am testing the arguments of Morse and Keohane ${ }^{11}$ in relation to global monetary governance. Legal rules and institutions created after the 2008 crisis, notably by what I called exit strategies, challenged the current global monetary order in two ways: by challenging the IMF as a central organization for monetary cooperation and by challenging the US dollar as the key currency for the Bretton Woods system. Emerging powers, especially in Asia, are promoting actions of "competitive regime creation"1, i.e. a "coalition of dissatisfied actors" is creating new arrangements for multilateral cooperation to challenge the existing institutional status quo, since the IMF's progress has been slow in expanding its political legitimacy and economic efficiency.

The main findings of this article are: (1) after the 2008 crisis, emerging powers in Latin America and Asia combined voice and exit strategies to challenge the actual legal framework for monetary governance; (2) voice strategies were focused on changes of the IMF power structure and were constructed in two forms: the G20 calls for a quota increase and shifts in voting power at the Fund, as well as proposals to reinforce the role of the SDR (Special Drawing Rights) as an international reserve asset; ${ }^{13}$ and (3) exit strategies involved the establishment or the reinforcement of parallel monetary institutions through bilateral and regional agreements, as well as the promotion of new global currencies to challenge the US dollar's hegemony as the key currency of the Bretton Woods system (e.g. bilateral currency swaps between central banks and pooling of foreign exchange reserves).

Up to the present, these strategies seem to have had only an incremental impact on the legal design of the global financial architecture. Voice strategies had a deferred and incomplete victory due to institutional iner-

11 MORSE, J. C., KEOHANE, R. O. Contested Multilateralism..., 2014 (note 10, above).

12 MORSE, J. C., KEOHANE, R. O. Contested Multilateralism..., 2014 (note 10, above).

13 The SDR was created in 1969. It is an international asset allocated by the IMF among all the SDR Department's participants. For details on the functioning of the SDR, see LASTRA, R. M. International and financial law, Oxford University Press, Oxford, 2015. 
tia. Only $5.7 \%$ of the Fund's voting power was allocated to emerging countries. Five years was needed to accomplish this movement due to the hostility of the U.S. Congress in confirming the quota increase. Nevertheless, the United States remains with veto power over key decisions at the Fund, retaining $16.5 \%$ of the voting share.

In 2015, the Chinese currency, the Renminbi, was included in the IMF's SDR basket of currencies. This decision took effect in October 2016. This asset, however, has minor practical relevance in the global monetary system, representing less than $3.2 \%$ of international reserves. ${ }^{14}$ Yet it can produce a symbolic effect: it could reinforce the emergence of alternatives to the US dollar as the main currency of the Bretton Woods system (a type of exit strategy).

Exit strategies have been relatively more successful. In fact, a type of monetary strategy viable in a global system of national monies, without capital controls, is the State ability and economic capacity of issuing a national currency accepted as global means of payment and vehicle for investments. The inclusion of the Renminbi in the IMF's SDR basket may be mainly symbolic as a voice strategy, but it reveals a path to the emergence of new global currencies.

Nonetheless, exit strategies are producing important consequences for the international economic architecture. They are reinforcing institutional fragmentation of the monetary system: fewer multilateral organizations, more flexible contracts at the regional and bilateral levels. As a consequence, they are contributing to adding more uncertainty to the handling of the next liquidity crises, since cooperation is based on central bank discretion rather than on international organizations with specific mandates at the global level.

Moreover, monetary structures based on exit strategies are not horizontal, as one might believe. Regional and bilateral agreements in the monetary field have a hierarchical component due to the hegemony of certain currencies in the global financial system. This hierarchical component reproduces an essential characteristic of international money ${ }^{15}$ : monetary orders are hierarchical

14 IMF-related assets (SDR holdings and reserve tranche) accounted for 3.4 percent of total international reserves at the end of 2013 (Source: IMF - https://www.imf.org/external/pubs/ft/ ar/2014/eng/pdf/a1.pdf)

15 BERNES, T. A., Jenkins, P., Mehrling, P., Neilson, D. China's and tend to continue to be so in the medium-term, even if emerging currencies could challenge the U.S. dollar's key role.

My analysis of exit strategies provides a different conclusion if compared to Armijo and Katada's ${ }^{16}$ investigation on the emerging powers' "financial statecraft". They argued that emerging economies' financial strategies "to date remain primarily defensive, aiming at participation rather than transformation of the existing international market and regulatory system". ${ }^{17} \mathrm{I}$ argue, in fact, that exit strategies already implemented by emerging powers have the potential to be successful in the medium and long-term, notably in Asia. Their financial strategies are based on very particular monetary knowledge: what the functions of international money are and how emerging countries' governments could effectively intervene in this regulatory and market environment - mainly, through central bank interventions and swaps.

To better evaluate exit and voice strategies, I propose to examine them from the perspective of how international money plays its role in the global financial system and how the US dollar as an international currency has evolved since the founding of the Bretton Woods system. The analysis of this global system based on national currencies is essential to understand how the management of international money impacts differently developed and developing countries, issuers and "consumers" of global currencies. It also enables the appraisal of how and why emerging powers are designing their strategies to challenge the Bretton Woods framework as exit strategies, while they simultaneously express their voice strategies.

In the first section, I present an analysis on the evolution of the Bretton Woods framework and how the US dollar became its key currency. Particularly, I will explore what constitutes international money and its functions at the global level. In the second section, the paper explores the institutional design of voice and exit strategies formulated by emerging powers in Asia and

engagement with an evolving international monetary system, CIGI special report, 2015, p. 5. Available at: <https://www.cigionline. org/sites/default/files/china_engagement_cigi-inet_special_report_web_0.pdf $>$. Last accessed: 10 April 2018.

16 ARMIJO, L. E., KATADA, S. N. Theorizing the financial statecraft of emerging powers, New Political Economy 20 (1), 2015. 17 ARMIJO, L. E., KATADA, S. N. Theorizing the financial..., at 58 . 
Latin America in the 2008 aftermath. I will stress the relationship between the functioning of international money and the emerging monetary structures underlying it. I also present some reflections on the practical consequences of emerging countries' monetary plans, notably their impact on the global monetary architecture. A concise conclusion follows.

\section{The GLOBAL FINANCIAL ARCHITECTURE: EVOLVING CHALLENGES IN MANAGING INTERNATIONAL MONEY}

The institutionalization of monetary cooperation, i.e. the enactment of rules and institutions, provides a framework in which economic actors (market and government agents) can assure the continued access to international money. The global monetary order provides international means of payment (liquidity) and institutions that can address balance of payment imbalances in times of crisis - i.e., to serve as lender of last resort. In the contemporary world, international money is represented by currencies managed at the national level but accepted as monetary standard across boundaries. These so-called "hard currencies" serve as vehicles for movement of capital.

The international monetary system is premised on hard currencies serving monetary functions at private and official levels (Table 1). To be qualified as such, a hard currency would be able to be traded in international transactions (medium of exchange), to be accepted for the settlement of obligations in trade and finance (means of payment), to serve as a denominator of international contracts as well as an anchor in monetary systems (unit of account) and to keep its value stable while being perceived as a credible vehicle for investments (store of value).
Table 1. Economic and institutional functions of hard currencies

\begin{tabular}{|l|l|l|l|l|}
\hline $\begin{array}{l}\text { Level / } \\
\text { Monetary } \\
\text { Functions }\end{array}$ & $\begin{array}{l}\text { 1. Medium } \\
\text { of Exchan- } \\
\text { ge }\end{array}$ & $\begin{array}{l}\text { 2. Me- } \\
\text { ans of } \\
\text { Payment }\end{array}$ & $\begin{array}{l}\text { 3. Unit of } \\
\text { account }\end{array}$ & $\begin{array}{l}\text { 4. Store of } \\
\text { value }\end{array}$ \\
\hline $\begin{array}{l}\text { 1. Private } \\
\text { use }\end{array}$ & $\begin{array}{l}\text { 1.1. Foreign } \\
\text { exchange } \\
\text { trading }\end{array}$ & $\begin{array}{l}\text { 1.2. Trade } \\
\text { and finan- } \\
\text { cial settle- } \\
\text { ments }\end{array}$ & $\begin{array}{l}\text { 1.3. Deno- } \\
\text { minator for } \\
\text { financial } \\
\text { transactions } \\
\text { and trade } \\
\text { invoicing }\end{array}$ & $\begin{array}{l}\text { 1.4. In- } \\
\text { vestment } \\
\text { currency }\end{array}$ \\
\hline $\begin{array}{l}\text { 2. Official } \\
\text { use }\end{array}$ & $\begin{array}{l}\text { 2.1. Inter- } \\
\text { vention } \\
\text { currency } \\
\text { and object } \\
\text { of bilate- } \\
\text { ral swap } \\
\text { contracts } \\
\text { between } \\
\text { central } \\
\text { banks }\end{array}$ & $\begin{array}{l}\text { 2.2. Settle- } \\
\text { ment of in- } \\
\text { ternational } \\
\text { obligations }\end{array}$ & $\begin{array}{l}\text { 2.3. Exchan- } \\
\text { ge rate } \\
\text { anchor }\end{array}$ & $\begin{array}{l}\text { 2.4. Reserve } \\
\text { currency } \\
\text { for central } \\
\text { banks }\end{array}$ \\
& & & \\
\hline
\end{tabular}

Source: based on the foundational work of Benjamin Cohen ${ }^{18}$ and the author's reflections on the means of payment function (column 2).

In the 1940s, through a treaty agreed upon by states, the Bretton Woods system aimed at reorganizing international monetary architecture. ${ }^{19}$ Bretton Woods was conceived as a system of "national monies" based on control of capital movements. This agreement established the IMF to carry out monetary cooperation. Initially, the Fund managed the dollar-gold system through control on exchange rate parity and, since the 1970s, it acts in an even more complex global credit-based system.

Similar to the domestic sphere, the international monetary environment is a credit-based system. Since its creation in the 1960s, the Eurocurrency market has assured the supply of international private money ${ }^{20}$,

18 COHEN, B. J. The geography of money, Ithaca, NY: Cornell University Press, 1998. COHEN, B. J. The Future of Sterling as an International Currency, Macmillan: London, 1971.

19 This is a very different framework if one compares to the monetary system during the international gold standard between 1879 and 1913. The development of this monetary system was based on unilateral actions taken by individual states. However, this feature does not imply that the gold standard was not managed, see McKinnon, R. The Eurocurrency market, Essays on International Finance, n. 125, Princeton University, 1977, pp. 3-10.

20 See: McKinnon, R. Private and official international money: the case for the dollar, Princeton: Princeton University Press, 1969. ; McKinnon, R. The Eurocurrency market, Essays on International Finance, n. 125, Princeton University, 1977; Kindleberger, C International money: a collection of essays, London-Boston: Allen \& Unwin, 1981, pp. 9-112; CARREAU, D. Le système monétaire 
a structure that has gained importance with increased financial globalization. A Eurocurrency is a currency held in a financial institution outside the country of its issuer. The Eurodollar is the most significant one and it is followed distantly by the euro and other hard currencies such as the sterling and the yen. ${ }^{21}$ This market is the most important money market at the global level, which creates and sustains global liquidity in hard currencies. ${ }^{22}$ The Eurocurrency market is a private, non-regulated and decentralized structure where global currencies are negotiated on a continum basis. Through it, international economic actors can have access to monetary vehicles to invest, or to settle obligations in foreign currencies at the global level.

This "private" legal structure is imperfectly connected to the Bretton Woods system of "official" money, i.e. onshore currencies issued by national systems and subjected to specific and very limited international obligations related to current account transactions (and not to capital account transactions). In fact, during normal times, economic actors presuppose that there is a par value between onshore (national money) and offshore currencies (i.e. the international money represented as Eurocurrencies, which serve as means of payment outside the issuer's country).

However, when crises arise, international money tends to "come back home": to financial institutions inside the issuer's country, which have access to central bank money as the last resort. The price of onshore currencies and Eurocurrencies tends to differ in global markets. As Merhling 23 explains, one symptom of the breakdown of the international money market in the 2008 crisis was a large and persistent spread between Eurodollar interest rates and the onshore dollar (the LIBOR-OIS spread).

international privé (UEM et euromarchés), 274 Recueil des Cours 309, 1998.; _. Souverainété monétaire et utilisation de la monnaie par les opérateurs privés. In Kahn (org.), Droit et monnaie: Etats et espace monétaire international, CREDIMI, Litec : Dijon, 1988.

21 Here, I am referring to the Eurocurrency market as a framework for Eurocurrencies and Eurobonds, i.e. monetary as well as investment vehicles in foreign currencies.

22 MERHLING, P. Elasticity and discipline in the global swap network, working paper for the conference 'China and the global financial system', Shangai Development Research Foundation, August, 2015, pp. 9-14. Available at: < https://www.ineteconomics. org/uploads/papers/WP27-Mehrling.pdf $>$. Last accessed 10 April 2018.

23 MERHLING, P. Elasticity and discipline in the global swap network..., 2015, pp. 13-14 (note 23, above).
Since its conception, the rules and the real practice of the Bretton Woods system greatly differed. ${ }^{24}$ The idea of its founders was to assure macroeconomic autonomy to states, a major intellectual change if one compares it to the international gold system before the World Wars. In the 1940s, the international monetary system was originally conceived as a global order in which different currencies were supposed to be used in international transactions without bierarchy among them. The agreement's original intention was to use national currencies symmetrically in foreign transactions.

Nevertheless, the US dollar became the key currency of the Bretton Woods system. In practical terms, the system evolved to a "fixed-rate dollar standard" in the $1960 \mathrm{~s} .{ }^{25}$ In this monetary order, born from practices of the post-Bretton Woods agreements, the US dollar and its issuer, the Federal Reserve (Fed), became the most important engines for the functioning of the international monetary system. The Eurodollar became the most important offshore currency in the world.

In fact, since the failure of the par value system in the 1970s, the US dollar and the Fed became even more central to the Bretton Woods system. Since the US dollar is no longer linked to gold by an international agreement, the Fed's monetary policy determines the value of this currency in global money markets and decisively influences its demand by other countries. In other words, the American central bank influences the value of the Eurodollar, the international money of the Bretton Woods order, even though the Fed has no direct control over this money created outside the US.

At the same time, with the increasing episodes of international crises after the 1970s, the IMF started to gain more power as global lender of hard currencies, with a growing number of credit operations. For instance, the Fund's total outstanding credit grew from US\$ 20bn in 1981 to US\$ 60bn in 1995, reaching US\$100bn in 2001 and more than US\$ 140bn in $2012 .{ }^{26}$ The consolidation of the Fund as an international lender of last

24 MCKINNON, R. The Rules of the Game: International Money in Historical Perspective, Journal of Economic Literature 31, 1993.

25 MCKINNON, R. The Rules of the Game..., 1993, at p. 15 (note 25, above).

26 MOHAN, R., KAPUR, M. Emerging powers and global governance: whither the IMF?, IMF working paper 15/219, 2015. Available at: < http://www.imf.org/external/pubs/ft/wp/2015/ wp15219.pdf>. Last accessed 10 April 2018. 
resort was heavily reinforced during crises in Asia and Latin America, in the $1990 \mathrm{ss}^{27}$ It was also a period in which the Fund was highly criticized for its approach to political conditionalities.

The Fund's international reserve asset - i.e. the SDR, created in 1969 -, however, was not successful. Since its creation, the percentage of this asset in the global foreign exchange reserves never exceeded $6 \%{ }^{28}$ The IMF Article of Agreements established that each member undertakes the obligation to make the SDR "the principal reserve asset in the international monetary system" (Article VIII, Section 7).

I believe the SDR failed, in the 1970s and the 1980s, because it did not evolve into a genuine currency. At that time, other international contracts (mainly, currency derivatives) had an important development at the global level and replaced units of account, such as the $\mathrm{SDR}$, as a more efficient instrument to hedge international financial operations. Since SDR-denominated claims, created by the initiative of economic actors ${ }^{29}$, did not evolve into significant means of payment and investment vehicles at the global level (such as the Eurocurrencies), the demand for this asset decreased. In contrast, the European Currency Unit - ECU (the embryo of the euro) was a supranational unit of account, created in the same context as the SDR and inspired by its design, which became a denominator for private contractual claims and a legal mechanism to settle international obligations between European economic actors $^{30}$. The difference is that the ECU evolved to an actual currency traded by private actors. The SDR re-

27 In the 1990s, with M. Camdessus as managing director, the IMF was the central organisation in monetary cooperation, formulating responses to the Asian and Latin American crises. For a comparison of the Fund's responses to emerging powers' crisis in the 1990s and in 2008, see DURAN, C. V. The international lender of last resort for emerging countries: a bilateral currency swap?, GEG working paper, n. 108, University of Oxford, 2015a. Available at: < https:// www.geg.ox.ac.uk/sites/geg/files/documents/WP_108\%20-020 The $\% 20$ International $\% 20$ Lender $\% 20$ of $\% 20$ Last $\% 20$ Resort $\% 20$ for $\% 20$ Emerging $\% 20$ Countries $\% 20-\% 20$ Camila $\% 20$ Duran.pdf $>$. Last accessed 10 April 2018.

28 OBSTFELD, M. The SDR as an international reserve asset: what future?, International Growth Centre, Rapid Response 11/0885, 2011.

29 GOLD, Sir J. Development of the SDR as reserve asset, unit of account and denominator: a survey, 16 Geo. Wash. J. Int'L. \& Econ. 1, 1981.

30 VISSOL, T. Les monnaies composites: innovation financière, innovation monétaire. In Kahn (org.), Droit et monnaie: Etats et espace monétaire international, CREDIMI, Dijon: Litec, 1998. mained an official asset with limited monetary functions and was restricted to the Fund's members.

However, the SDR represents an unconditional liquidity, which can be readily exchanged for hard currencies, such as the US dollar. It represents a potential claim on international money. This is the main economic function of the SDR in the current system and what induced its demand from emerging and developing countries after the 2008 crisis.

At the global level, the American currency is still the main reserve for central banks, representing more than $60 \%$ of international reserves. ${ }^{31}$ Consequently, emerging and developing countries rely on the supply of a hard currency by the Fed (in the US) and the Eurodollar market (outside the US). In times of crisis, they can have access to it through a multilateral institution, the IMF. Since the Fund is not a central bank, this monetary system is based on "limited discounting" 32 , i.e. the economic capacity of the multilateral organization is linked to the contribution of member countries in hard currencies.

I argue that there is an inherent inconsistency in the Bretton Woods framework. The IMF is the main organization for global monetary cooperation. Yet it cannot issue the major currency for global transactions. The Fund is merely an intermediary between the issuers of hard currencies, or surplus countries, and deficit countries. The price of this intermediation is political conditionalities (in ex ante or ex post forms). The Fed has national mandates, but it issues and manages the key currency for the Bretton Woods system.

In the 2000s, benefiting from high prices in international commodity markets, emerging countries in Latin America and Asia could accumulate foreign exchange reserves to counter capital flows (Figure 1). This type of unilateral action had precautionary purposes. ${ }^{33}$ The motivation behind the accumulation of reserves was attributed to political stigma towards the Fund, created by political conditionalities imposed in lending programs during the $1990 \mathrm{~s}^{34}$.

31 The US dollar even achieved more than $70 \%$ of global reserves in the end of the 1990s. Source: IMF statistics; COFER.

32 KINDLEBERGER, C., ALIBER, Z. R. Manias, panics, and crashes: a history of financial crises. New York: Palgrave Macmillan, 2011 [1978].

33 It had also intervention objectives to influence the value of the emerging countries' currencies and incentivize exports.

34 IMF - International Monetary Fund. Review on flexible 
Figure 1. G20 emerging countries in Asia and Latin America: foreign exchange reserve accumulation (19902015)

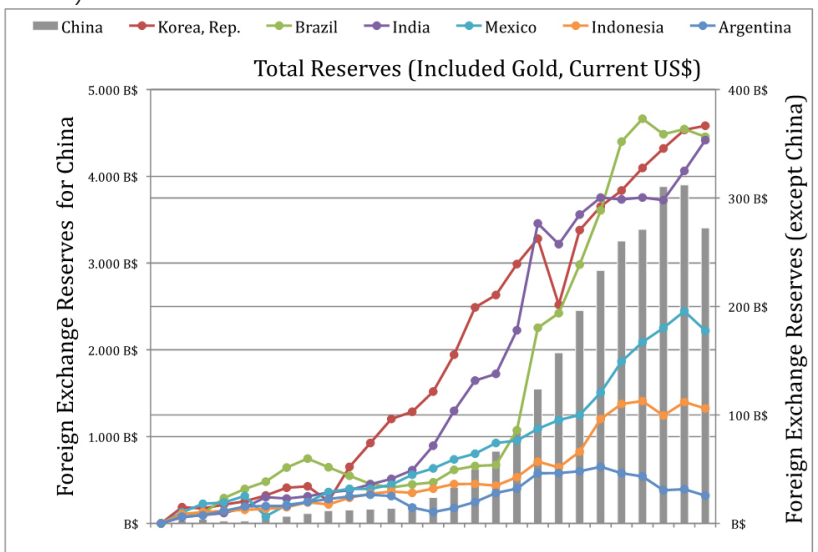

Source: World Bank. Elaborated Developed by the author.

Notwithstanding the economic costs of reserve accumulation, this type of unilateral action secured political leverage for emerging countries once the 2008 crisis hit. ${ }^{35}$ They could choose their lender of last resort. A small number of emerging powers had direct access to currency swaps directly with the Fed (i.e. Brazil, Mexico, South Korea and Singapore), instead of going to the IMF. In addition, emerging countries, using the power granted by their reserves, formalized bilateral commitments with the Fund as lenders, and not as borrowers.

Furthermore, in the 2008 aftermath, these countries were able to formulate new agreements for monetary cooperation to respond to future liquidity crises by pooling their reserves in US dollars. The accumulation of reserves created economic and political conditions for emerging powers to design exit and voice strategies for monetary cooperation. They were able to challenge the status quo of the Bretton Woods system, since they could accumulate the key currency for the functioning of the global monetary order.

credit line, the precautionary and liquidity line, and the rapid financing instrument, IMF Policy Paper, Washington DC, 2014. Available at: <https://www.imf.org/en/Publications/Policy-Papers/ Issues/2016/12/31/Review-of-the-Flexible-Credit-Line-the-Precautionary-and-Liquidity-Line-and-the-Rapid-PP4846>. Last accessed 10 April 2018.; IEO - Independent Evaluation Office of the International Monetary Fund. IMF response to the financial and economic crisis: evaluation report. Washington DC: IMF, 2014. Available at: <http://www.ieo-imf.org/ieo/pages/EvaluationImages227.aspx >. Last accessed 10 April 2018.

35 DURAN, C. V. The international lender of last resort for emerging countries..., 2015a (note 28, above).
In fact, in 2008, the Fed confirmed the US dollar hegemony and played the role of lender of last resort for selected market and countries. ${ }^{36}$ Thus, the management of the crisis reaffirmed the US dollar's centrality: quantitative easing policy (as well as the latter "taper tantrum") sent shockwaves through countries worldwide, the so-called 'spillover' effects. The former Brazilian Minister of Finance, Guido Mantega, coined the term "currency war" in 2010 and blamed the US for the "tsunami" of liquidity that flooded emerging countries. ${ }^{37}$ Nevertheless, the Fed's actions supported the supply of international money at the global monetary order along with multilateral organizations, such as the IMF.

\section{Bretton Woods system IN THe 2008 AFTERMATH: WHICH MONETARY STRATEGIES?}

The IMF power structure is predominantly governed by traditional powers reflecting the context of the Bretton Woods agreements in the 1940s and the consolidation of the US leadership in the post-world wars. ${ }^{38}$

36 See: AIZENMAN, P. Selective swap arrangements and the global financial crisis: analysis and interpretation, International Review of Economics and Finance 19 (3), 2010.; ALLEN, W., MOESSNER, R. Central bank co-operation and international liquidity in the financial crisis of 2008-9”, LSE Financial Markets Group Paper series 187, 2010.; MOESSNER, R., Allen, W. Banking crises and the international monetary system in the Great Depression and now, BIS working paper 333, 2010. Available at: < https://www.bis.org/ publ/work333.htm>. Last accessed 10 April 2018.; MCDOWELL, D. The US as 'sovereign international last-resort lender': the Fed's currency swap programme during the great panic of 2007-2009, New Political Economy, v. 17, n. 2, 2012; The emergent international liquidity network: central bank cooperation after the global financial crisis", working paper presented at the 2015 ISA annual conference.; BROZ, J. L. The Politics of Rescuing the World's Financial System: The Federal Reserve as a Global Lender of Last Resort, San Diego: University of California, 2014.; DESTAIS, C. Central Bank Currency Swaps and the International Monetary System, Policy brief CEPII, Sep, 2014. Available at: <http://www.cepii. $\mathrm{fr} / \mathrm{CEPII} / \mathrm{en} /$ publications/pb/abstract.asp?NoDoc $=7203>$. Last accessed 10 April 2018.

37 See the news at the Financial Times "Brazil in 'currency war' alert”, September 27, 2010 (available at: http://www. ft.com/cms/s/0/33ff9624-ca48-11df-a860-00144feab49a. html\#axzz41CrZoFUD)

38 The US decisively consolidated this role contributing to the management of the Bretton Woods' par value system in the 1960s. Kindleberger developed what became known as the "theory of hegemonic stability". According to him, the world needs at least one leader (a "bénévole" hegemon) to sustain the global monetary order. See: KINDLEBERGER, C. The World in Depression, Berkeley: University of California Press, 1973. 
Even if their share in global GDP (in PPP basis) for the Group of 7 (G7) is approximately $32 \%$, the G7 countries (Canada, France, Germany, Italy, Japan, the United Kingdom and the United States) accumulate more than $41 \%$ of the Fund's voting shares. The corresponding share for emerging and developing countries at the Fund is $44 \%$, despite their GDP representing almost $57 \%$ of global wealth. ${ }^{39}$

Currently, the Fund is an organization of 189 nations. Despite the growing membership adherence after the 1960s and the 1990s, with the decolonization of countries in Africa and Asia and the breakdown of the Soviet Union, ${ }^{40}$ the distribution of the Fund's quotas changed little over time. Quotas are an important feature of the IMF. They determine its total economic capacity and represent a permanent commitment of each member to lend to the organization. They are also a crucial element of the IMF's structure, because quotas define the limits to borrow, the voting power and the allocation of SDRs for each member. ${ }^{41}$

The Fund conducts general quota reviews in five-year intervals (Article III, Section 2 (a), Articles of Agreement). There have been 14 general reviews to date. The far-reaching reforms in the Fund's history were proposed in 2010, as part of a package to manage the 2008 crisis. ${ }^{42}$ This group of reforms doubled its economic capacity (from US\$329bn to US\$ 659bn) and shifted $6 \%$ of the quotas' share towards emerging and developing countries (representing $5.7 \%$ of voting power). This quota reform was called by the G20 in 2009 and 2010, notably during the London and Seoul Summits. However, despite persistent calls by the group ${ }^{43}$ the US Congress only confirmed the Fund's

39 Source: IMF statistics.

40 The IMF membership grew from 69 countries in 1960 to 138 in 1978.

41 The actual quota formula is defined as a weighted average of the country's GDP (50\%), its degree of economic openness (30\%), the economic variability $(15 \%)$ and its international reserves $(5 \%)$. Source: IMF website.

42 This package was influenced by the 2008 Quota and Voice Reforms implemented in 2011. As a result of this ad hoc review, the Fund had an increase of US $\$ 27 \mathrm{bn}$ in its economic capacity and the quotas were distributed among 54 countries. It also tripled the basic votes of low-income countries.

43 The last call was expressed at the Antalya Summit, in Turkey. The Communiqué registered: "We remain deeply disappointed with the continued delay in implementing the IMF quota and governance reforms agreed in 2010 . The 2010 reforms remain our highest priority for the IMF and we urge the United States to ratify these reforms as soon as possible. Mindful of the aims of the 2010 re- quota change at the end of 2015 . Thus, the $14^{\text {th }}$ general quota review became effective on January 26, 2016. ${ }^{44}$

In addition to calls for greater participation and representation in the Fund, emerging powers looked for other forms of monetary cooperation. First, they formalized note purchases and the New Arrangements to Borrow (NAB) with the Fund, investing as lenders of the IMF. These actions reveal that they are looking for other ways of participating in the Bretton Woods system. Secondly, they reinforced or created parallel monetary structures, such as the Asian Chiang Mai Initiative Multilateralization (CMIM ${ }^{45}$ and the BRICS ${ }^{46}$ Contingent Reserve Arrangement (CRA).

\subsection{Voice monetary strategies}

There were four main voice strategies implemented by these countries: (1) calls through the G20 meetings for the quota's increase and voting power shift in the IMF structure; (2) calls for new allocation of SDRs; (3) formalization of temporary financial agreements with the Fund as lenders (note purchases and NAB); and (4) specifically in relation to China, calls for a more important role for the Fund's SDR as a global currency and calls for the inclusion of the Renminbi in the SDR basket. ${ }^{47}$ This last strategy aimed at challenging the US dollar's hegemony in the Bretton Woods system.

forms, we ask the IMF to complete its work on an interim solution that will meaningfully converge quota shares as soon as and to the extent possible to the levels agreed under the 14th General Review of Quotas" (item 17, G20 Leaders' Communiqué Antalya Summit, 15-16 November 2015).

44 Source: IMF. See the official description of the quota's reform at: http://www.imf.org/external/np/exr/facts/quotas.htm

45 This regional monetary arrangement is formed by the ten members of the Association of Southeast Asian Nations (ASEAN) and Japan, China and South Korea ("plus 3" countries).

46 BRICS is an acronym for Brazil, Russia, India, China and South Africa.

47 The G20 communiqué of the Antalya Summit endorsed the Chinese interests in relation to the SDR: "We reaffirm that the Special Drawing Rights (SDR) basket composition should continue to reflect the role of currencies in the global trading and financial system and look forward to the completion of the review of the method of valuation of the SDR" (item 17, G20 Leaders' Communiqué Antalya Summit, 15-16 November 2015). 
Table 2. G20 emerging powers in Asia and Latin America: voice monetary strategies in the 2008 aftermath

\begin{tabular}{|l|l|}
\hline \multicolumn{1}{|c|}{ Voice strategies } & \multicolumn{1}{|c|}{ G20 emerging powers } \\
\hline $\begin{array}{l}\text { Calls for quota review (IMF's } \\
2010 \text { general quota review) }\end{array}$ & $\begin{array}{l}\text { China, South Korea, Indonesia, } \\
\text { India, Brazil, Mexico and Ar- } \\
\text { gentina }\end{array}$ \\
\hline $\begin{array}{l}\text { Call for new allocations of } \\
\text { SDRs }\end{array}$ & $\begin{array}{l}\text { China, South Korea, Indonesia, } \\
\text { India, Brazil, Mexico and Ar- } \\
\text { gentina }\end{array}$ \\
\hline $\begin{array}{l}\text { NAB and/or note purchase } \\
\text { with the Fund }\end{array}$ & $\begin{array}{l}\text { China, South Korea, India, Bra- } \\
\text { zil and Mexico }\end{array}$ \\
\hline $\begin{array}{l}\text { Renminbi as a currency of the } \\
\text { Fund's SDR basket and calls for } \\
\text { a more important role for the } \\
\text { SDR as a global currency }\end{array}$ & China \\
\hline
\end{tabular}

Source: IMF and G20 meetings' minutes. Developed by the author.

In the immediate aftermath of the 2008 crisis, the biggest emerging powers in Latin America and Asia (for instance, China, South Korea, India, Brazil and Mexico) expected to be recognized in a different way at the international level: not as deficit countries, but instead as surplus countries. The engagement of some emerging economies as lenders rather than borrowers of the IMF (Table 2) suggests that the Fund may in fact be the site of future cooperation on global monetary governance, even as a political stalemate over reforms continues to undercut its legitimacy and mires the institution in inertia.

As a whole, I argue that the emerging powers' voice strategies had a partial and delayed victory. In January 2016, the IMF had finally confirmed a quota increase, which expanded its economic capacity in dealing with liquidity crises. It also contributes to additional certainty in monetary support, since the quotas are more permanent financial commitments if compared to note purchases or other temporary arrangements, such as the NAB.

Nevertheless, the increase of quotas combined with its correspondent voting power modification only impacted incrementally the Fund's governance. Merely $5.7 \%$ of voting power was shifted towards emerging countries, notably to the benefit of China, Brazil, India, Mexico and South Korea. Argentina had a slight cut in its voting share due to the devaluation of its currency for the calculation of GDP size, reflecting its economic conditions after the 2001 crisis. $^{48}$ Indonesia had a very small addition to its voting power. For the countries in this sample, the individual increase in voting shares is identified below (Table 3). Only for China was this voice strategy a relatively more important victory. China saw its voting share almost double (from 3.6\% to 6\%) and it is today the third-largest member country, after the US and Japan.

Table 3. IMF voting shares before and after the 2010 general quota review (effective on January 26, 2016)

\begin{tabular}{|c|c|c|}
\hline $\begin{array}{c}\text { G20 emerging } \\
\text { powers } \\
\text { (Asia and Latin } \\
\text { America) }\end{array}$ & $\begin{array}{c}\text { As of March 2, } \\
\mathbf{2 0 1 1} \\
(\text { in } \%)^{1}\end{array}$ & $\begin{array}{c}\text { Post-2010 Reform } \\
\text { As of January 26, } \\
\mathbf{2 0 1 6} \\
\text { (in \%) }\end{array}$ \\
\hline China & 3.651 & 6.068 \\
\hline South Korea & 1.328 & 1.730 \\
\hline Indonesia & 0.947 & 0.950 \\
\hline India & 1.882 & 2.627 \\
\hline Brazil & 1.377 & 2.217 \\
\hline Mexico & 1.430 & 1.795 \\
\hline Argentina & 0.964 & 0.661 \\
\hline
\end{tabular}

Source: IMF (Link: https://www.imf.org/external/ $\mathrm{np} / \mathrm{sec} / \mathrm{pr} / 2011 /$ pdfs/quota_tbl.pdf)

The shares reallocated to emerging countries came mostly at the expense of European members - in particular, Germany, France, United Kingdom, Netherlands and Belgium. The US still maintains relevant veto power at the Fund (16.5\% of the voting share), since key decisions require a majority of $85 \%$ - i.e. the adjustment in quotas, any amendment to the Articles of Agreement and the allocation of SDRs.

The relative failure of voice strategies could also be attributed to the forum used to articulate them. My main argument is that the G20, as an informal governmental network, could not promote substantial structural changes to the global monetary system. International private money (i.e. "Eurocurrencies") is global private liquidity ${ }^{49}$, which is used by foreign exchange markets and in-

48 Argentina, however, sustained at the G20 the IMF reform and called for a more important role for emerging economies. That was the declaration of Miguel Pesce, vice governor of the Argentinean central bank in 2009 ("Nuestro país buscará impulsar cambios en el sistema de prestámos del Fondo y conseguir un mayor poder de voto para las economías emergentes", see at: http://www.infobae. com/2009/02/11/431190-para-argentina-reformar-el-fmi-esprioridad-cumbre-del-g20).

49 For the economic perspective on global liquidity, see also LANDAU, J. P. Global liquidity: public and private. In Global di- 
ternational banking institutions. From 2007, this market relied on central banks, issuers of hard currencies (and not on the IMF), to sustain the par value between onshore and offshore money. For instance, the Fed assured the par value between the onshore US dollar and the Eurodollar by providing financial support to US branches of foreign institutions, and currency swaps with foreign central banks, including emerging countries.

Starting from December 2007, the Fed established a temporary network of swaps based on bilateral agreements with central banks in advanced economies (the Bank of England, the European Central Bank - ECB, the Bank of Japan, the Swiss National Bank, the Reserve Bank of Australia, the Bank of Canada, Danmarks Nationalbank, the Reserve Bank of New Zealand, Norges Bank and Sveriges Riksbank), and later with emerging countries (Brazil, South Korea, Singapore and Mexico). In 2013, the Fed set up a permanent and unlimited network of swaps with the ECB, the Bank of Japan, the Bank of England, the Swiss National Bank and the Bank of Canada, the so-called "C6". ${ }^{50}$ These swaps tend to sustain the regular functioning of the Eurodollar money market, offering direct access to international money by the Fed through central banks in advanced economies. In this sense, the US unilateral actions supported the Bretton Woods system by saving international private money in US dollars.

At the peak of the crisis, the Fed's currency swaps attained a value of US\$ 580bn in December 2008 representing more than $45 \%$ of its total assets. ${ }^{51}$ At that time, as a comparison, the Fund had only SDR 238bn in quotas (approximately US $\$ 355 \mathrm{bn}$ at the December 1, 2008 exchange rate). Its funding was boosted by the G20 meetings after 2009 through temporary additional pledges and committed resources, not as readily available funding. Also in 2009, the IMF attempted to create two lending instruments based on ex ante conditions and with precautionary effects, i.e. the Flexible Credit Line (FCL) and the Precautionary Credit Line (PCL). However, the demand for these instruments was low and it remains low. ${ }^{52}$ Only Mexico, Colombia and Poland had

mensions of unconventional monetary policy, Federal Reserve Bank of Kansas City Jackson Hole symposium, 2013.

50 MERHLING, P. Elasticity and discipline in the global swap network..., 2015, p. 15 (note 24, above).

51 LANDAU, J. P. Global liquidity..., 2013, p. 49 (note 51, above).

52 IMF - International Monetary Fund. Review on flexible credit line..., 2014 (note 34, above). access to the FCL and Morocco to the PCL. Mexico and Colombia are still attached to this instrument and they are suffering from "exit stigma". ${ }^{53}$

Therefore, focusing on the IMF instead of central bank networks was perhaps a less effective political action implemented by emerging countries. As argued by Helleiner ${ }^{54}$, during the 2008 crisis management, the currency swaps between the Fed and other central banks were greater in value and in importance for stabilizing international turbulence compared to the Fund's lending agreements. The Fund's new lending instruments and SDR allocations came too late (only in 2009), when the Fed had already implemented the major actions months before.

From an economic perspective, as suggested by Mehrling ${ }^{55}$, more important than official borrowing or reserve flows to manage liquidity crises is the network of central bank swaps that serve as backstop to money markets. In his view, the role of central banks as bankers' banks (and not government banks) is central to understand what stabilized money markets in the post-2008 crisis. The modern international private money (offshore Eurodollar market) is sustained by central bank actions, not by governments and their borrowing relations with international organizations, such as the IMF.

In this sense, voice strategies aimed at influencing the global monetary landscape could be more usefully implemented at the central bankers' fortress for cooperation, the Bank for International Settlements (BIS), rather than at the Fund. The BIS is a site for central bank cooperation for financial regulation and supervision, and could be more utilized for monetary governance as well, since bilateral agreements based on currency swaps became a key instrument to manage global crises.

In addition, at the time of the 2008 crisis, the Fund was suffering from political stigma related to its lending programs implemented during the 1990s. The major institutional flaw of the Bretton Woods system - i.e. an international organization (the IMF) in charge of monetary cooperation and a national central bank (the Fed)

53 IMF - International Monetary Fund. Review on flexible credit line..., 2014 (note 34, above).

54 HELLEINER, Eric. The Status Quo Crisis: Global Financial Governance after the 2008 Crisis, Oxford: Oxford University Press, 2014.

55 MERHLING, P. Elasticity and discipline in the global swap network..., 2015 (note 24, above). 
responsible for the issuance and the management of the key currency - surfaced aggressively. Thus, taking into account the economic and political context of 2008 , the IMF could contribute less to the stability of the global (private) monetary system compared to the network of developed economies' central banks, issuers of hard currencies.

Meanwhile, the choice of emerging countries in becoming lenders of the IMF was perhaps a less valuable strategy. It may have contributed to the delay of the US Congress' confirmation of the 2010 reform. It clearly vocalized the economic power of emerging countries and it had a symbolic effect. Yet it ruled out the pressing needs of the Fund's financing by providing temporary resources. The lack of sufficient resources could have been used as a source of economic pressure. It proved to be useful to force the US Congress to confirm the Fund's quota increases in other critical historical moments, particularly in 1978 and 1983, during the 7th and 8th general quota review. This was a tactic employed twice by De Larosière, managing director of the Fund between 1978 and 1987. ${ }^{56}$ A late US legislative confirmation of the $14^{\text {th }}$ quota review (only after five years) could also be explained by the fact that the Fund's resources were, in a certain way, assured if larger countries were to apply for it.

Finally, the revival of the old idea involving a global monetary standard, ${ }^{57}$ i.e. the reinforcement of the IMF's SDR, was expressed by the president of the People's Bank of China (PBoC) in 2009, Zhou Xiaochuan. The statement "Reform the international monetary system" was a contribution to rethink the global order that resulted as a practice of the Bretton Woods agreements based on one key currency. ${ }^{58}$ None of the SDR refor-

56 MOHAN, R., KAPUR, M. Emerging powers and global governance..., 2015, p. 24; BOUGHTON, J. M. Silent Revolution..., p. 859 .

57 Originally, Keynes proposed the "bancor" as a global currency to be issued (and not merely allocated) by the Bretton Woods' monetary institution (named by him as the "International Clearing Union"). For the historical and innovative Keynes Plan, KEYNES, J. M. Proposals for an International Clearing Union (Keynes Plan). In: HORSEFIELD, J. K. (ed.), The International Monetary Fund 1945-1965, vol. III: Documents, IMF, Washington, (1969 [1943]).. Nussbaum identifies the first idea of world money in the Italian work of Gasparo Scaruffi, in 1582 (Alitinonfo). His plan was based in an idea of the moneta imaginaria, which would serve as a global unit of account. See: NUSSBAUM, A. A note on the idea of world money, Political Science Quartely, v. 64, n. 3, 1949.

58 XIAOCHUAN, Z. Reform the international monetary system, BIS, 23 March, 2009. Available at: <https://www.bis.org/review/ ms vocalized by M. Xiaochuan was adopted, except the proposal of new general allocation called for during the G20 Summit in London.

Accomplished by the Fund in August 2009, the SDR allocation, despite its unprecedented size (US\$250bn), had a minor economic impact for emerging powers. Since the allocation of SDRs is defined by quotas, the impact tends to be less significant for the largest emerging countries. The SDR is more valuable, as an unconditional source of financial support, for smaller developing countries. For instance, Brazil, South Korea and Mexico are examples of how low the impact of the SDR was: all had formalized currency swaps with the Fed during the crisis (US\$30bn each) that outstripped ten times their SDR holdings (at about US\$ 3 bn each). Meanwhile, Ecuador, a smaller developing country, coped with the crisis by using loans from the Latin American Reserve Fund (FLAR) on three occasions: in 2009 (US\$ 480 million), 2010 (US\$ 515 million) and in 2014 (US\$ 618 million). These values are close to Ecuador's SDR holdings, a total of US\$ 411 million.

Despite the incomplete victory of voice strategies among emerging powers, the major Chinese success came in 2015 with the inclusion of the Renminbi in the SDR value along with the US dollar, the euro, the sterling and the yen. ${ }^{59}$ Even if, up to the present, the SDR basket is only the "backdoor" of the Bretton Woods system, I believe that this decision potentially has the capacity to transform the global monetary architecture.

The Renminbi carries a different concept of international money, which is based on the idea of "managed convertibility". ${ }^{60}$ China declared that it intends to maintain capital account management, which means: (1) macroprudential management of the private sector's external debt; (2) management of short-term speculative capital flows; (3) adoption of temporary capital con-

r090402c.pdf>. Last accessed 10 April 2018.

59 The Fund's decision will take effect in October 2016.

60 XIAOCHUAN, Z. IMFC Statement by the Honorable Zhou Xiaochuan Governor of the IMF for China to the Thirty-First Meeting April 18, 2015. Available at: <https://www.imf.org/External/spring/2015/imfc/statement/eng/chn.pdf > . Last accessed 10 April 2018 LUBIN, D. China and the SDR: a big change in 2015?, Emerging Markets Macro View, Citi Research Economics, March, 2015.; DURAN, C. V. Avoiding the next liquidity crunch: how the G20 must support monetary cooperation to increase resilience to crisis, GEG / BSG policy brief, University of Oxford, October, 2015b. Available at: <http://www.geg.ox.ac.uk/avoiding-nextliquidity-crunch-how-g20-must-support-monetary-cooperationincrease-resilience-crisis>. Last accessed 10 April 2018. 
trols in case of "abnormal" fluctuations in international markets, or balance of payments problems; and (4) monitoring of cross-border financial transactions, which involve money laundering and financing of terrorism, as well as the exploitation of tax havens. ${ }^{61}$

Thus, China may promote significant modifications to the practices of the Fund's concept of "freely usable currency", which represented, up to present, free and ready convertibility of hard currencies. The inclusion in the SDR basket was also especially relevant for another Chinese plan: a type of exit strategy, which tends to challenge the US dollar hegemony over time.

\subsection{Exit monetary strategies}

From the perspective of monetary governance, exit plans seem to confirm the idea of "contested multilateralism" proposed by Morse and Keohane. ${ }^{62}$ Monetary strategies designed as exit options created competing institutional arrangements through bilateral and regional agreements based on currency swaps.

The main exit strategies formulated by G20 emerging powers were: (1) the reinforcement or the creation of parallel monetary arrangements based on the "pooling" of reserves in US dollars; and (2) specifically in relation to China and to a lesser extent South Korea, India and Indonesia, the creation of alternatives to the US dollar through the formalization of bilateral agreements between central banks in national currencies with trade purposes and/or short-term liquidity financing. China is the main emerging economy driving changes in the international monetary system by formulating exit strategies.
Table 4. G20 emerging powers in Asia and Latin America: exit monetary strategies in the 2008 aftermath

\begin{tabular}{|c|c|}
\hline $\begin{array}{l}\text { Emerging } \\
\text { powers }\end{array}$ & Exit strategies \\
\hline China & $\begin{array}{l}\text { Reinforcement of the CMIM } \\
\text { Total of US } \$ 240 \text { bn } \\
\text { Creation of the BRICS' CRA } \\
\text { Total of US\$ } 100 \text { bn } \\
\text { Bilateral currency swaps in Renminbi ( } 32 \\
\text { agreements - Hong Kong SAR, South Korea, } \\
\text { Singapore, Australia, Malaysia, Indonesia, Thailand, } \\
\text { New Zealand, Mongolia, Pakistan, Sri Lanka, } \\
\text { Kazakhstan, Uzbekistan, European Central } \\
\text { Bank, United Kingdom, Canada, Brazil, Russia, } \\
\text { Switzerland, Argentina, United Arab Emirates, } \\
\text { Qatar, South Africa, Chile, Ukraine, Turkey, } \\
\text { Hungary, Belarus, Iceland, Albania, Suriname and } \\
\text { Armenia) } \\
\text { Total: equivalent of US\$465.67bn }\end{array}$ \\
\hline $\begin{array}{l}\text { South } \\
\text { Korea }\end{array}$ & $\begin{array}{l}\text { Reinforcement of the CMIM } \\
\text { Total of US\$240bn } \\
\text { Bilateral currency swaps in Korean Won ( } 4 \\
\text { agreements - China, Australia, Indonesia and } \\
\text { Malaysia) } \\
\text { Total: equivalent to US\$ } 74.5 \mathrm{bn}\end{array}$ \\
\hline Indonesia & $\begin{array}{l}\text { Reinforcement of the CMIM } \\
\text { Total of US } \$ 240 \mathrm{bn} \\
\text { Bilateral currency swaps in Rupia ( } 3 \text { agreements - } \\
\text { China, Korea and Japan) } \\
\text { Total: equivalent to US\$13.8bn }\end{array}$ \\
\hline India & $\begin{array}{l}\text { Creation of the BRICS’ CRA } \\
\text { Total of US\$100bn } \\
\text { Bilateral currency swaps in Rupee (Japan and } \\
\text { SAARC nations - Afghanistan, Bangladesh, } \\
\text { Bhutan, Maldives, Nepal, Pakistan and Sri Lanka). } \\
\text { Total: equivalent to US\$52bn }\end{array}$ \\
\hline Brazil & $\begin{array}{l}\text { Creation of the BRICS' CRA } \\
\text { Total of US\$100bn } \\
\text { Bilateral currency swaps in Real (1 agreement - } \\
\text { China) } \\
\text { Total: equivalent of US\$18.3bn } \\
\text { Creation of the SML - System of Payments in } \\
\text { Local Currencies (Argentina and Uruguay) } \\
\text { Total: equivalent to US\$160 million }\end{array}$ \\
\hline Mexico & No exit strategy announced \\
\hline Argentina & $\begin{array}{l}\text { Bilateral currency swaps in Peso (1 agreement - } \\
\text { China) } \\
\text { Total: equivalent of US\$2.5bn } \\
\text { Creation of the System of Payments in Local } \\
\text { Currencies - SML (Brazil and Uruguay) } \\
\text { Total: equivalent to US\$160 million }\end{array}$ \\
\hline
\end{tabular}

Source: IMF 2015; World Bank and central banks' websites; The Hindu, The Financial Times; Brazilian Law n. $11.803 / 2008$. Developed by the author.

The first exit strategy was materialized in two arrangements: the expansion and multilateralization of the
61 XIAOCHUAN, Z. IMFC Statement by the Honorable Zhou Xiaochuan..., 2015, p. 5.

62 MORSE, J. C., KEOHANE, R. O. Contested Multilateralism..., 2014 (note 10, above). 
Asian Chiang Mai Initiative (CMI) and the establishment of the BRICS' CRA. Asian countries added to the former CMI agreement, created originally in 2000: (i) a multilateral framework for currency swaps based on a single contractual agreement and a regional macroeconomic office in Singapore for surveillance, (ii) a precautionary credit instrument (inspired by the Fund's FCL and PCL), (iii) an increase of the members' financial commitments (from US $\$ 80 \mathrm{bn}$ in 2000 to US\$240bn in 2014); and (iv) a decrease of de jure link with the IMF lending programs (from $80 \%$ to $70 \%$ ). ${ }^{63}$ The CRA was created by the BRICS countries in 2014 and it was inspired by the CMIM. The total amount of the agreement reaches US\$100bn. ${ }^{64}$

Both agreements have an inherent flaw (a shared trait with the IMF): they are dependent on the supply of US dollars by the Fed and the continuity of reserve accumulation as a model of unilateral action. This strategy, based on regional arrangements, reveals the emerging countries' dependence on the supply of international money. Therefore, their capacity in promoting significant changes in global monetary governance may be less effective than one would expect.

In fact, these new regional arrangements have a specific legal structure: they are international treaties, which formalize currency swaps between national authorities (i.e. central banks). They are not organized as international institutions, such as the IMF. Regional agreements based on swaps entail pre-commitment of resources, which are not "transferred" to an institution with a specific mandate. Instead, all these reserves in US dollars are held in national hands until the activation of a swap contract. It means that, in an event of

63 For the history of the CMI, see SUSSANGKARN, C. Chiang Mai Initiative Multilateralization: origin, development, and outlook, Asian Economic Policy Review 6, 2011.and GRIMES, W. W. The Asian Monetary Fund reborn? Implications of Chiang Mai Initiative Multilateralization, Asia Policy 11, 2011.

64 For more details on the BRICS CRA, see its treaty published at Brazilian Ministry of Foreign Affairs' website: http://brics6.itamaraty.gov.br/media2/press-releases/220-treaty-for-the-establishment-of-a-brics-contingent-reserve-arrangement-fortaleza-july- 15 In the 2012 BRICS Summit, countries were also discussing also a master agreement for credit in local currencies. See the statement: "[w]e welcome the conclusion of the Master Agreement on Extending Credit Facility in Local Currency under BRICS Interbank Cooperation Mechanism and the Multilateral Letter of Credit Confirmation Facility Agreement between our EXIM/Development Banks. We believe that these Agreements will serve as useful enabling instruments for enhancing intra-BRICS trade in coming years" (item 18, BRICS’ Delhi Declaration, March 2012). a crisis, there is no guarantee that a central bank will actually provide the resources. For instance, the BRICS' members can opt out of providing support in the CRA framework and can request early repayment if a problem occurs in the balance of payment. This is also the case for the CMIM, even if it has already established a macroeconomic office in Singapore, which could be an embryo of a monetary organization in the future.

A specific political factor was relevant to the expansion of monetary structures based on swaps: the growing power of national central banks at the international level in developed and emerging countries ${ }^{65}$. The Great Moderation (1984-2008) and the process of de jure and de facto political autonomy achieved after the 1990s empowered central banks inside their countries' bureaucracies. These institutions could influence the political choices in designing monetary arrangements in the 2008 aftermath. International institutional arrangements based on currency swaps (instead of international organizations) allow central banks to maintain control over foreign exchange reserves they manage, or the currency they issue.

Notably Asian emerging countries, i.e. China, South Korea, India and Indonesia, are heavily using an exit strategy model, which could be relatively more successful in changing the international monetary architecture: they are formalizing currency swaps in national currencies. China has 32 agreements with different countries as well as offshore structures to assure payment settlement and investments in Renminbi. ${ }^{66}$ The total amount of the swap network reaches RMB 3.159 tri (equivalent of US $\$ 465,67 \mathrm{bn})$.

This type of monetary structure is based on specific knowledge: how international money is used at the global level (through Eurocurrencies) and how State institutions (mainly, central banks) interact with financial markets to assure the international value of a currency (as a backstop in times of crisis).

65 DURAN, C. V. The international lender of last resort for emerging countries..., 2015a (note 28, above).

66 IMF - International Monetary Fund. Review on flexible credit line, the precautionary and liquidity line, and the rapid financing instrument, IMF Policy Paper, Washington DC, 2014. Available at: <https://www.imf.org/en/Publications/Policy-Papers/ Issues /2016/12/31/Review-of-the-Flexible-Credit-Line-the-Precautionary-and-Liquidity-Line-and-the-Rapid-PP4846>. Last accessed 10 April 2018.; BERNES, T. A., Jenkins, P., Mehrling, P., Neilson, D. China's engagement..., 2015 (note 16, above). 
Thus, China clearly has two levels of exit strategies: regional arrangements as an alternative to the Bretton Woods institutions (such as the IMF), and the promotion of the Renminbi as an international currency to exit from the US dollar-centered order. Both strategies are linked to each other, since member countries of these new regional arrangements are still dependent on the US dollar. However, the choice of using another currency depends on the capacity of the $\mathrm{PBoC}$ to assure access to the Renminbi even in times of crisis (i.e. through bilateral swaps), which is the main challenge of this type of "contested multilateralism" in monetary governance.

The functioning of international money could also explain why emerging countries have been investing in voice and exit strategies at the same time. It is not just about using exit to amplify voice. ${ }^{67} \mathrm{It}$ involves concerns about political legitimacy of the IMF as well as economic efficiency of monetary agreements. The most efficient way of shifting power from the US towards other actors and structures is investing in the emergence of new global currencies. To do so, the contribution of the Fund tends to be small: in the short-term, mainly though the "symbolism" of the SDR basket and, in the long-term, only promoting a fundamental modification on the concept and operations of international money.

The network of currency swaps between emerging powers' central banks seem to be a more important arrangement to promote this exit plan and to implement the strategy of contested multilateralism. In this regard, countries in Asia are more engaged in this type of monetary scheme. Emerging powers in Latin America are merely recipients of these contracts. Argentina, for instance, is using swaps with China to exchange Renminbi for US dollars in foreign exchange markets. ${ }^{68}$ It is an indirect way of obtaining international money, until the Renminbi consolidates itself as a global currency. Mexico seems to be the most loyal emerging power to the Bretton Woods institutions: it has announced no exit strategy. The only NAFTA ${ }^{69}$ member, who has swaps in

67 HIRSCHMAN, A. O. Exit, voice, and loyalty..., 1970 (note 8 , above).

68 See the news entitled: "El Banco Central logró convertir a dólares 3086 millones del swap con China”, La Nation December 22, 2015 available at: http://www.lanacion.com.ar/1856429-el-banco-central-logro-convertir-a-dolares-3086-millones-del-swap-conchina

69 The North American Free Trade Agreement (NAFTA) comprises Unites States, Mexico and Canada.
Renminbi with China, is Canada.

Brazil and Argentina are re-investing in a traditional Latin American way of monetary cooperation: the establishment of clearinghouses and official credit lines between central banks mainly for trade purposes (and not for short-term financing). The SML is a clearinghouse to settle commercial transactions using the Brazilian real and Argentinean peso (as well as the Uruguayan peso)..$^{70}$ The total amount, however, is very low if compared to the emerging power's central bank network in Asia.

Despite the inertia of international monetary schemes, the most effective plan, as alternative to the Bretton Woods system, seems to promote more cross-border transactions in new currencies. The institutional framework to sustain these transactions is under construction: a network of central bank swaps in national currencies. The institutional intent is to build a public backstop for short-term financing in times of crisis, when economic actors challenge the par value between onshore and Eurocurrencies.

However, it is important to emphasize that these structures come with a cost. Regional treaties based on swaps, or on the less formal network of central bank arrangements in national currencies, tend to contribute to the fragmentation of global monetary governance. Contested multilateralism in monetary affairs can promote more uncertainty in times of crisis. Even though exit plans created more sources of liquidity, they are based on flexible contracts among national authorities.

\subsection{Practical consequences of $\mathbf{G} 20$ emerging powers' voice and exit strategies}

The combination of relatively failed voice strategies with potentially successful exit arrangements has a practical and critical consequence: the institutional fragmentation of the global monetary system. Emerging powers with growing foreign exchange reserves, managed by independent central banks, are changing the landscape of monetary cooperation. ${ }^{71}$ The system tends to be more

70 The SML is a continum of the Agreement on Reciprocal Payments and Credits (CCR), created in 1982 by the ALADI (Latin American Integration Association) and formalized by the central banks of central banks of Argentina, Bolivia, Brazil, Chile, Colombia, Ecuador, Mexico, Paraguay, Peru, the Dominican Republic, Uruguay and Venezuela.

71 DURAN, C. V. The international lender of last resort for emerging countries..., 2015a (note 28, above). 
complex and fragmented with the decentralization of multilateral cooperation.

New forms of regional and bilateral monetary arrangements have been reinforced or created in the post-crisis world. This institutional change points to more currency competition in the future ${ }^{72}$, despite the current centrality of the US. ${ }^{73}$ The interesting institutional feature of these global monetary initiatives is that they are not established as international organizations, but rather as networks of currency swaps (i.e. contracts).

Emerging powers are developing the same model of cooperation established by advanced economies. I refer to temporary currency swaps established by the Fed after 2007, as well as the permanent and unlimited network announced in 2013. However, these structures carry more uncertainty in times of crisis because swaps rely on national decisions for the transfer of resources and central banks have national mandates and interests as priorities. Generally, swaps are three-year term renewable contracts and limited to a certain value. Thus, this legal structure tends to create more transaction costs. It is also difficult to anticipate how the interplay between the three levels (multilateral, regional and bilateral) will take place in a crisis. Systemic risks and contagion can arise out of this complex structure of liquidity. In this sense, contested multilateralism can promote less certainty in the event of an economic downturn.

Furthermore, this multifaceted network of global liquidity is not horizontal. It is essentially hierarchical. Even if new actors, such as G20 emerging countries, gained more power at the international level and are trying to internationalize their own currencies, they are still relying on international money issued by developed countries to build regional arrangements in the short and medium-term. Monetary governance reveals that institutional inertia is hard to overcome. The "international hierarchy of money"74 tends to be replicated in monetary arrangements, with a seemingly less important role for international organizations at the multilateral level (Figure 2).

72 EICHENGREEN, B. Exorbitant privilege: the rise and the fall of the dollar and the future of the International Monetary System, Oxford: Oxford University Press, 2011.

73 COHEN, B. J., BENNEY, T. M. What does the international currency system really look like?, Review of International Political Economy v. 21, n.5, 2014.

74 BERNES, T. A., Jenkins, P., Mehrling, P., Neilson, D. China's engagement..., 2015 (note 16, above).
Figure 2. The international hierarchy of money

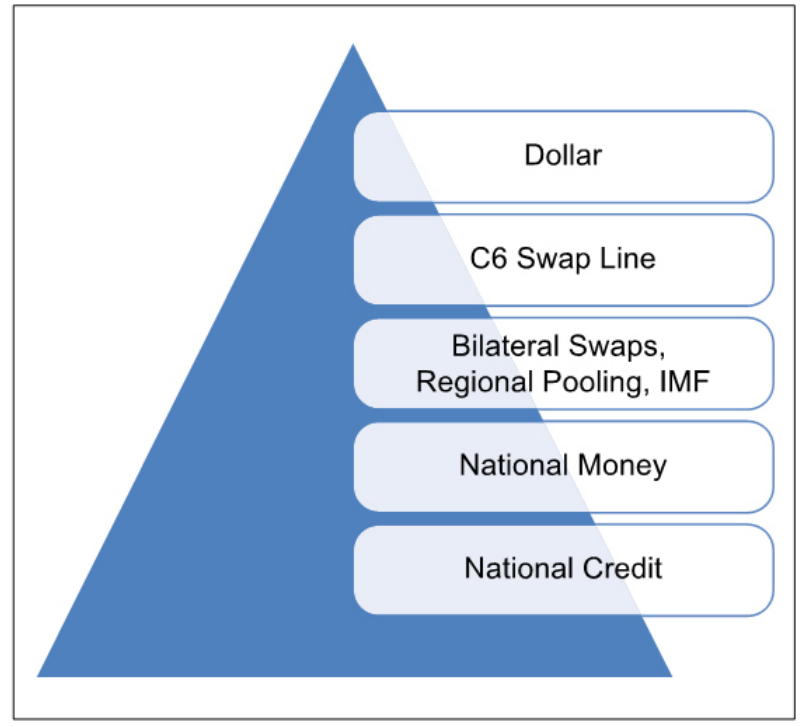

Source: Bernes et al. (2015)

Global liquidity in hard currencies from different sources is available to developed countries, emerging powers and less developed countries as a result of the fragmentation of the monetary system. Central banks gained more space to define their counterparties in swaps at the international level and can limit or expand the options for each country's access to financial support in the event of a crisis.

Multilateral institutions tend to play a less important role for emerging powers. They seem to prefer avoiding multilateral institutions and to rely on reserve accumulation, or regional arrangements based on swaps for liquidity in traditional hard currencies. Since there is no international organization with a specific mandate, once a crisis hits, it can be difficult to assess the solvency of their counterparties and uncertainty tends to be greater.

\section{Final Considerations}

Despite G20 emerging powers' efforts to change the global monetary landscape through voice and exit strategies, to date they have not caused significant challenges to the international monetary structure, but only incremental changes in the Bretton Woods institutions. Voice and representation reforms at the IMF merely secured a symbolic power shift towards emerging powers. The US remains with its institutional veto power over the Fund's key decisions. 
In addition, the parallel monetary arrangements created or reinforced by emerging powers in the 2008 aftermath rely on the supply of international money by the Fed and the permanence of foreign exchange reserve accumulation, with its inherent economic costs. These regional structures are contributing to the fragmentation of the global monetary system without guaranteeing certain and timely access to liquidity in the event of a crisis. They are based on currency swaps among central banks (i.e. national authorities), instead of an international organization with specific global mandates.

Currently, emerging powers and other developing countries seem to depend on the Chinese prospective, and to a lesser extent South Korean and Indian initiatives, in assuring (1) new global currencies that could be used as an alternative to the US dollar and (2) new institutional providers (i.e. central banks) to assure liquidity backstops in times of crisis. This is the model of exit strategy, which could be more successful in challenging the actual framework of the Bretton Woods system. Nonetheless, even if a more multicurrency world emerges in the future, the inherent hierarchical component of a monetary order tends to persist. Some global currencies would be stronger than others. Monetary orders are hierarchical and at present seem to be more fragmented than they were prior to the 2008 crisis. Contested multilateralism in monetary affairs may produce more uncertainty on how countries will respond to the next financial crisis.

\section{References}

AIZENMAN, P. Selective swap arrangements and the global financial crisis: analysis and interpretation, International Review of Economics and Finance 19 (3), 2010.

ALLEN, W., MOESSNER, R. Central bank co-operation and international liquidity in the financial crisis of 2008-9", LSE Financial Markets Group Paper series 187, 2010.

BERNES, T. A., Jenkins, P., Mehrling, P., Neilson, D. China's engagement with an evolving international monetary system, CIGI special report, 2015. Available at: $<$ https://www.cigionline.org/sites/default/files / china_engagement_cigi-inet_special_report_web_0.pdf $>$. Last accessed 10 April 2018.
ARMIJO, L. E., KATADA, S. N. Theorizing the financial statecraft of emerging powers, New Political Economy 20 (1), 2015.

BOUGHTON, J. M. Silent Revolution: The International Monetary Fund, 1979- 1989, International Monetary Fund, Washington DC, 2010.

BROZ, J. L. The Politics of Rescuing the World's Financial System: The Federal Reserve as a Global Lender of Last Resort, San Diego: University of California, 2014.

CARREAU, D. Le système monétaire international privé (UEM et euromarchés), 274 Recueil des Cours 309, 1998.

Souverainété monétaire et utilisation de la monnaie par les opérateurs privés. In Kahn (org.), Droit et monnaie: Etats et espace monétaire international, CREDIMI, Litec : Dijon, 1988.

COHEN, B. J. The geography of money, Ithaca, NY: Cornell University Press, 1998.

The Future of Sterling as an International Currency, Macmillan: London, 1971.

COHEN, B. J., BENNEY, T. M. What does the international currency system really look like?, Review of International Political Economy v. 21, n.5, 2014.

de VRIES, M. G., HORSEFIELD, J.K. The International Monetary Fund, 1945- 1965: Twenty Years of International Monetary Cooperation, Volume II: Analysis, International Monetary Fund, Washington DC, 1969.

de VRIES, M. G. The International Monetary Fund, 1966-1971: The System Under Stress, Volume I: Narrative, International Monetary Fund, Washington DC, 1976.

The International Monetary Fund, 1972-1978, Volume I: Narrative and Analysis, International Monetary Fund, Washington DC, 1985.

DESTAIS, C. Central Bank Currency Swaps and the International Monetary System, Policy brief CEPII, Sep, 2014. Available at: <http://www.cepii.fr/CEPII/en/ publications $/ \mathrm{pb} /$ abstract.asp? NoDoc $=7203>$. Last accessed 10 April 2018.

DURAN, C. V. The international lender of last resort for emerging countries: a bilateral currency swap?, GEG working paper, n. 108, University of Oxford, 2015a. Available at: < https://www.geg.ox.ac.uk/sites/geg/files/ documents/WP_108\%20-\%20The\%20Internatio- 
nal $\% 20$ Lender $\% 20$ of $\% 20$ Last $\% 20$ Resort $\% 20$ for $\% 20$ Emerging\%20Countries\%20-\%20Camila\%20Duran. pdf $>$. Last accessed 10 April 2018.

Avoiding the next liquidity crunch: how the G20 must support monetary cooperation to increase resilience to crisis, GEG / BSG policy brief, University of Oxford, October, 2015b. Available at: <http://www. geg.ox.ac.uk/avoiding-next-liquidity-crunch-how-g20must-support-monetary-cooperation-increase-resilience-crisis>. Last accessed 10 April 2018.

EICHENGREEN, B. Exorbitant privilege: the rise and the fall of the dollar and the future of the International Monetary System, Oxford: Oxford University Press, 2011.

GOLD, Sir J. Development of the SDR as reserve asset, unit of account and denominator: a survey, 16 Geo. Wash. J. Int'L. \& Econ. 1, 1981.

GRIMES, W. W. The Asian Monetary Fund reborn? Implications of Chiang Mai Initiative Multilateralization, Asia Policy 11, 2011.

HELLEINER, Eric. The Status Quo Crisis: Global Financial Governance after the 2008 Crisis, Oxford: Oxford University Press, 2014.

HIRSCHMAN, A. O. Exit, voice, and loyalty: Responses to decline in firms, organizations, and states. Cambridge: Harvard University Press, 1970.

IEO - Independent Evaluation Office of the International Monetary Fund. IMF response to the financial and economic crisis: evaluation report. Washington DC: IMF, 2014. Available at: <http://www.ieo-imf.org/ieo/pages/EvaluationImages227.aspx>. Last accessed 10 April 2018.

IMF - International Monetary Fund. Review on flexible credit line, the precautionary and liquidity line, and the rapid financing instrument, IMF Policy Paper, Washington DC, 2014. Available at: <https://www.imf.org/ en/Publications/Policy-Papers/Issues/2016/12/31/ Review-of-the-Flexible-Credit-Line-the-Precautionaryand-Liquidity-Line-and-the-Rapid-PP4846>. Last accessed 10 April 2018.

. Review of the method of valuation of the SDR initial considerations, IMF Policy Paper, August 3, 2015. Available at: <https://www.imf.org/en/Publications/ Policy-Papers/Issues/2016/12/31/Review-of-the-Method-of-Valuation-of-the-SDR-Initial-ConsiderationsPP4975>. Last accessed 10 April 2018.
JAMES, H. International Monetary Cooperation Since Bretton Woods, Oxford: Oxford University Press, 1996.

KEYNES, J. M. Proposals for an International Clearing Union (Keynes Plan). In: HORSEFIELD, J. K. (ed.), The International Monetary Fund 1945-1965, vol. III: Documents, IMF, Washington, (1969 [1943]).

KINDLEBERGER, C. The World in Depression, Berkeley: University of California Press, 1973.

International money: a collection of essays, London-Boston: Allen \& Unwin, 1981.

KINDLEBERGER, C., ALIBER, Z. R. Manias, panics, and crashes: a history of financial crises. New York: Palgrave Macmillan, 2011 [1978].

LASTRA, R. M. International and financial law, Oxford University Press, Oxford, 2015.

LANDAU, J. P. Global liquidity: public and private. In Global dimensions of unconventional monetary policy, Federal Reserve Bank of Kansas City Jackson Hole symposium, 2013.

LELART, M. Le système de l'écu privé: comment as t-il fonctionné, comment aurait-il prévaluer ?, Revue d'Economie Financière 113, 2013.

LUBIN, D. China and the SDR: a big change in 2015?, Emerging Markets Macro View, Citi Research Economics, March, 2015.

MERHLING, P. Elasticity and discipline in the global swap network, working paper for the conference 'China and the global financial system', Shangai Development Research Foundation, August, 2015. Available at: < https://www. ineteconomics.org/uploads/papers/WP27-Mehrling. pdf>. Last accessed 10 April 2018.

MCDOWELL, D. The US as 'sovereign international last-resort lender': the Fed's currency swap programme during the great panic of 2007-2009, New Political Economy, v. 17, n. 2, 2012.

. The emergent international liquidity network: central bank cooperation after the global financial crisis", working paperpresented at the 2015 IS A annual conference.

MCKINNON, R. The Rules of the Game: International Money in Historical Perspective, Journal of Economic Literature 31, 1993.

The Eurocurrency market, Essays on International Finance, n. 125, Princeton University, 1977. 
Private and official international money: the case for the dollar, Princeton: Princeton University Press, 1969.

MOESSNER, R., Allen, W. Banking crises and the international monetary system in the Great Depression and now, BIS working paper 333, 2010. Available at: < https://www.bis.org/publ/work333.htm>. Last accessed 10 April 2018.

MOHAN, R., KAPUR, M. Emerging powers and global governance: whither the IMF?, IMF working paper 15/219, 2015. Available at: < http://www.imf.org/ external/pubs/ft/wp/2015/wp15219.pdf>. Last accessed 10 April 2018.

MORSE, J. C., KEOHANE, R. O. Contested Multilateralism. The Review of International Organizations v. 9, n. 4, 2014.

NUSSBAUM, A. A note on the idea of world money, Political Science Quartely, v. 64, n. 3, 1949.

OBSTFELD, M. The SDR as an international reserve asset: what future?, International Growth Centre, Rapid Response 11/0885, 2011.

SUSSANGKARN, C. Chiang Mai Initiative Multilateralization: origin, development, and outlook, Asian Economic Policy Review 6, 2011.

VISSOL, T. Les monnaies composites: innovation financière, innovation monétaire. In Kahn (org.), Droit et monnaie: Etats et espace monétaire international, CREDIMI, Dijon: Litec, 1998.

XIAOCHUAN, Z. IMFC Statement by the Honorable Zhou Xiaochuan Governor of the IMF for China to the Thirty-First Meeting April 18, 2015. Available at: <https://www.imf. org/External/spring/2015/imfc/statement/eng/chn. pdf>. Last accessed 10 April 2018.

. Reform the international monetary system, BIS, 23 March, 2009. Available at: < https://www.bis.org/review/r090402c.pdf>. Last accessed 10 April 2018.

\section{ACKNOWLedgements}

I would like to acknowledge and thank the Department of Legal Theory and Philosophy of Law of the Faculty of Law at the University of São Paulo (USP) and all the members of the Oxford-Princeton GLF programme, notably professors Ngaire Woods, Bob Keohane, John Ikenberry, Emily Jones and Thomas Hale, Alexa Zeitz, Taylor St John and all the GFL fellows. Also, I am incredibly grateful to professors John Armour (Oxford) and Rosa Lastra (Queen Mary University of London). Furthermore, I had the opportunity to discuss early versions of this article at the Law Department of the University of Oxford, the Institute of International Relations (IRI) of the University São Paulo, the University Lumière Lyon 2 and at the Queen Mary University of London. I am in doubt to the comments of Dan Awrey (Oxford); Alberto do Amaral (USP); Maria Antonieta del Tedesco Lins, Felipe Pereira Loureiro, Adriana Schor, Feliciano de Sá Guimarães, Michelle Ratton Sanchez Badin, Caio Borges and all the members of the "NEPEI" (group of international political economy) of the IRI - USP; Sylvie Bernigaud, Guillaume Protière, Geneviève Iacono and the $\mathrm{PhD}$ students of Lyon 2; and Daniel Wang, Valsamis Mitsilegas, Isobel Helene Roele, Ruth Fletcher, Gabriel Gari and Maksymilian Del Mar (Queen Mary University of London). Matheus Prates (IRI) also provided an important support for the empirical research. All remaining errors are mine.

(Footnotes)

1 Shares prior to the entry in effect of the ad hoc 2008 Voice and Participation Reform. 
Para publicar na Revista de Direito Internacional, acesse o endereço eletrônico www.rdi.uniceub.br ou www.brazilianjournal.org.

Observe as normas de publicação, para facilitar e agilizar o trabalho de edição. 